\title{
Contrasting geochemical signatures on land from the Middle and Late Permian extinction events
}

\author{
NATHAN D. SHELDON*, RAMANANDA CHAKRABARTI†, GREGORY J. RETALLACK! \\ and ROGER M. H. SMITHฯ \\ *Department of Geological Sciences, University of Michigan, Ann Arbor, MI 48109, USA (E-mail: \\ nsheldon@umich.edu) \\ $\dagger$ Centre for Earth Sciences, Indian Institute of Science, Bangalore 560012, India \\ $\ddagger$ Department of Geological Sciences, University of Oregon, Eugene, OR 97403, USA \\ IKaroo Palaeontology Department, South African Museum, Cape Town, South Africa
}

Associate Editor - Adrian Immenhauser

\begin{abstract}
The end of the Palaeozoic is marked by two mass-extinction events during the Middle Permian (Capitanian) and the Late Permian (Changhsingian). Given similarities between the two events in geochemical signatures, such as large magnitude negative $\delta^{13} \mathrm{C}$ anomalies, sedimentological signatures such as claystone breccias, and the approximate contemporaneous emplacement of large igneous provinces, many authors have sought a common causal mechanism. Here, a new high-resolution continental record of the Capitanian event from Portal Mountain, Antarctica, is compared with previously published Changhsingian records of geochemical signatures of weathering intensity and palaeoclimatic change. Geochemical means of discriminating sedimentary provenance (Ti/Al, U/Th and La/Ce ratios) all indicate a common provenance for the Portal Mountain sediments and associated palaeosols, so changes spanning the Capitanian extinction represent changes in weathering intensity rather than sediment source. Proxies for weathering intensity chemical index of alteration, $\Delta W$ and rare earth element accumulation all decline across the Capitanian extinction event at Portal Mountain, which is in contrast to the increased weathering recorded globally at the Late Permian extinction. Furthermore, palaeoclimatic proxies are consistent with unchanging or cooler climatic conditions throughout the Capitanian event, which contrasts with Changhsingian records that all indicate a significant syn-extinction and postextinction series of greenhouse warming events. Although both the Capitanian and Changhsingian event records indicate significant redox shifts, palaeosol geochemistry of the Changhsingian event indicates more reducing conditions, whereas the new Capitanian record of reduced trace metal abundances ( $\mathrm{Cr}, \mathrm{Cu}, \mathrm{Ni}$ and $\mathrm{Ce}$ ) indicates more oxidizing conditions. Taken together, the differences in weathering intensity, redox and the lack of evidence for significant climatic change in the new record suggest that the Capitanian mass extinction was not triggered by dyke injection of coal-beds, as in the Changhsingian extinction, and may instead have been triggered directly by the Emeishan large igneous province or by the interaction of Emeishan basalts with platform carbonates.
\end{abstract}

Keywords Antarctica, greenhouse climate, mass extinctions, palaeoclimate, palaeosols, Palaeozoic, weathering. 


\section{INTRODUCTION}

The end of the Palaeozoic is marked by two large mass-extinction events, near the end of the Middle Permian (Capitanian ca 260.4 Ma; Zhou et al., 2002; Retallack et al., 2011) and one near the end of the Late Permian and Palaeozoic as a whole (Changhsingian; ca 252.2 Ma; Mundil et al., 2004; Reichow et al., 2009; Shen et al., 2011). The Late Permian mass extinction is the largest in the history of higher life, with more than $90 \%$ of species going extinct in both marine (Jin et al., 2000; Erwin et al., 2002) and terrestrial (Retallack, 1995) ecosystems (reviewed in Chen \& Benton, 2012). The Middle Permian mass extinction was less severe, but was still comparable in magnitude to the CretaceousPalaeogene extinction among marine (Stanley \& Yang, 1994; Wang et al., 2004; Bond \& Wignall, 2009; Wignall et al., 2012; McGhee et al., 2013), and terrestrial (Ward et al., 2005; Retallack et al., 2006) animals and plants (Stevens et al., 2011).

Because the Global Standard Section and Point (GSSP) for the basal Triassic is defined by the first appearance of the conodont Hindeodus parvus and the mass extinction is at a variable stratigraphic level below that (Retallack et al., 2011), direct correlation between marine and terrestrial records is difficult. Instead, many workers use a ubiquitous, extremely large negative carbon isotopic anomaly $\left(\delta^{13} \mathrm{C}\right.$ greater than $-5 \%$ marine; greater than $-10 \%$ continental) at the mass extinction, both in marine (e.g. Fio et al., 2010) and continental (e.g. Retallack et al., 2005) settings. Retallack et al. (2006) recognized a similar magnitude negative $\delta^{13} \mathrm{C}$ anomaly at various marine (e.g. Lai et al., 2008) and continental Capitanian sections. The similarity between the carbon cycle perturbations during both extinction events has been taken as evidence of a common causal mechanism, specifically, intrusion of coal-beds by feeder dykes associated with the Emeishan (Capitanian) and Siberian (Changhsingian-Griesbachian) Traps flood basalt large igneous provinces (LIP; Retallack et al., 2006; Retallack \& Jahren, 2008; Wignall et al., 2009). Here, that idea is tested by comparing a new end-Guadalupian continental record (Fig. 1) from Portal Mountain, Antarctica, with previously published continental records of the end-Permian from Antarctica and other parts of both Gondwana and Laurentia.

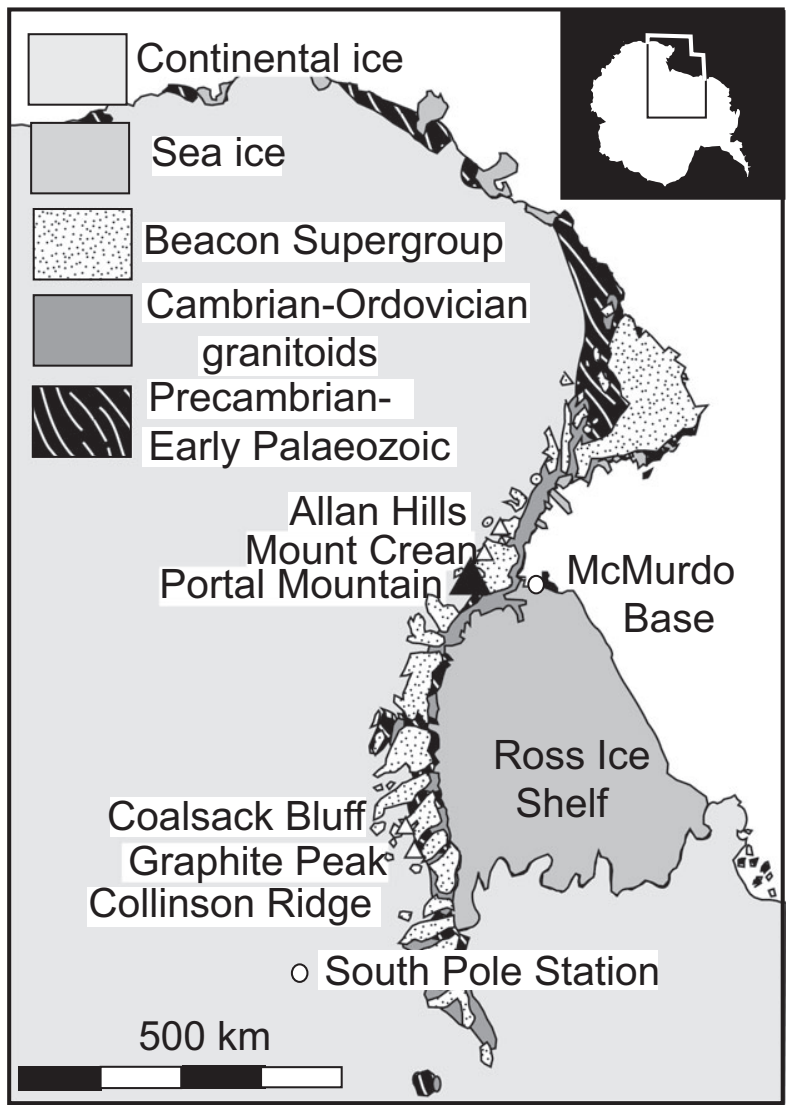

Fig. 1. Location map. Portal Mountain (shown with a filled symbol) is located in the Central Transantarctic Range relatively close to a number of other endGuadalupian and end-Permian localities. Modified after Retallack et al. (2006).

\section{Key features of the Late Permian mass- extinction event on land}

In addition to the ubiquitous large negative $\delta^{13} \mathrm{C}$ anomaly, a number of other common features have been recognized at continental Late Permian sites. One key feature of all of the sites is the absence of coal globally until the Middle Triassic (Retallack, 1995; Retallack et al., 1996). Another is a shift in fluvial style from meandering to braided streams that has been associated with the loss of continental vegetation (Sephton et al., 2005), and which has been documented in South Africa (Ward et al., 2000), Russia (Newell et al., 1999), Australia (Michaelson, 2002) and Antarctica (Sheldon, 2006a). Similarly, 'claystone breccias' have been found immediately above the last Permian coal in Antarctica, Australia and South Africa, and have been interpreted as soil erosion event horizons similar to modern forest responses to clearcutting, which is 
thought to be analogous to a plant extinction event (Retallack, 2005). A number of authors have also documented significant increases in chemical weathering across the Permian-Triassic boundary in both continental (Antarctica, Sheldon, 2006a; Australia, Retallack et al., 2011) and marine (Algeo \& Twitchett, 2010; Algeo et al., 2011a,b) settings, and have attributed the enhanced weathering to a rapid global warming event (Sheldon, 2006a). This conclusion is supported by modelling results that indicate that the negative $\delta^{13} \mathrm{C}$ anomaly could only be produced by a significant input of methane (which oxidizes rapidly to $\mathrm{CO}_{2}$ ) to the atmosphere during the Changhsingian mass-extinction event (Berner, 2002; Retallack \& Jahren, 2008). Both in the oceans and on land, recovery of floras and faunas was delayed by continued climatic perturbations (indicated by additional negative $\delta^{13} \mathrm{C}$ anomalies) in the earliest Triassic (Retallack et al., 2011; Irmis \& Whiteside, 2012). Finally, there is a strong redox response towards extremely reducing conditions in waterlogged palaeosols at a number of high-palaeolatitude Gondwanan sites (Sheldon \& Retallack, 2002; Sheldon, 2006a), although that feature has not been observed in lower palaeolatitude sites than Australia (for example, China, Thomas et al., 2011).

\section{Regional stratigraphic relations in Antarctica}

In contrast to other Permian successions (for example, China), there is no direct dating of the Victoria Land, Antarctica, so local chronology relies on palaeobotany (e.g. Farabee et al., 1990, 1991; Collinson et al., 1994), and regional correlation of both geochemistry (Fig. 2) and sedimentary marker beds (e.g. Isbell \& Cuneo, 1996). The age of the Weller Coal Measures (Fig. 2) is broadly constrained to the Middle Permian, based on the undivided Protohaploxpinus zone palynomorphs, which correlate with Australian Middle Permian palynozone 4 (Isbell \& Cuneo, 1996; Retallack et al., 2006), while also ranging into Late Permian palynozone 5 (Askin, 1997; Isbell \& Askin, 1999). At Portal Mountain, while the range of a number of plants (for example, Gangamopteris and Palaeovitaria; Fig. 2) is truncated at the stratigraphic level identified as the Capitanian extinction by Retallack et al. (2006), a variety of Late Permian macrofossils (Glossopteris flora; Vertebraria) continue for another $c a$ $100 \mathrm{~m}$ stratigraphically, before their extinction at the Changhsingian extinction event and the lithological contact between the Weller Coal
Measures and Feather Conglomerate (see fig. 3 of Retallack et al., 2006). Unique palaeosols (Dolores pedotype of Retallack et al., 2006) found only in the earliest Triassic that indicate extremely reducing conditions (Sheldon \& Retallack, 2002) are present at Portal Mountain and six other Antarctic Changhsingian sites (Sheldon, 2006a), and provide an additional stratigraphic constraint at Portal Mountain (Retallack et al., 2006). The large magnitude negative carbon isotopic excursion associated with the palaeobotanically identified Capitanian extinction (Fig. 2) has been documented at 17 other sites globally (Retallack et al., 2006), including both marine and terrestrial successions, providing an additional chemostratigraphic age constraint.

\section{METHODS}

\section{Field and laboratory methods}

A $23 \mathrm{~m}$ section spanning the Capitanian massextinction level (Figs 2 and 3A; Retallack et al., 2006) was logged on a ridge east of Portal Mountain, south Victoria Land, Antarctica (78.10784 ${ }^{\circ} \mathrm{S}, 159 \cdot 29979^{\circ} \mathrm{E}, 2107 \mathrm{~m}$ elevation). A total of 29 rock samples were collected from the main section, along with 11 additional samples from a second section offset laterally from the first by $c a 20 \mathrm{~m}$, to examine two stratigraphically equivalent sections spanning the Changhsingian mass-extinction event level (Fig. 3A). Samples were crushed and powdered, and then $0.2 \mathrm{~g}$ $( \pm 0 \cdot 0005 \mathrm{~g})$ was placed either into Teflon [inductively coupled plasma-mass spectrometer (ICPMS)] or graphite crucibles [inductively coupled plasma-optical emission spectrometry (ICPOES)]. The ICP-MS samples were heated and digested using a 2:1 mixture of $\mathrm{HF}$ and $\mathrm{HClO}_{4}$ acids, and then diluted with nitric acid. Fusions were made for ICP-OES analysis by adding $1 \mathrm{~g}$ of $\mathrm{LiBO}_{2}$ to the graphite crucibles, which were then placed in a muffle furnace set to $950^{\circ} \mathrm{C}$ for $25 \mathrm{~min}$. The resulting glass bead was dissolved in $200 \mathrm{ml}$ of $5 \% \mathrm{HNO}_{3}$ acid and digested. Wholerock geochemical analyses were performed by a combination of inductively coupled plasmaatomic emission spectroscopy (ICP-AES; major elements) and ICP-MS (trace elements) at the NERC ICP Facility at Royal Holloway (University of London). Results were calibrated using four internal and two international standards (Qlo-1 and Q-2). Analytical uncertainty is less than $0 \cdot 1 \%$ for major elements, and less than $5 \%$ for 
trace elements and rare earth elements (REE). The data are compiled as Supporting Information.

Quantifying weathering and pedogenesis A variety of geochemical proxies have been developed to characterize weathering and pedogenesis in palaeosols and associated sedimentary rocks (reviewed in Sheldon \& Tabor, 2009). All of the proxies for pedogenesis rely on molar ratios of the element in question, which is given as $m_{x}$ for each of the following proxies.

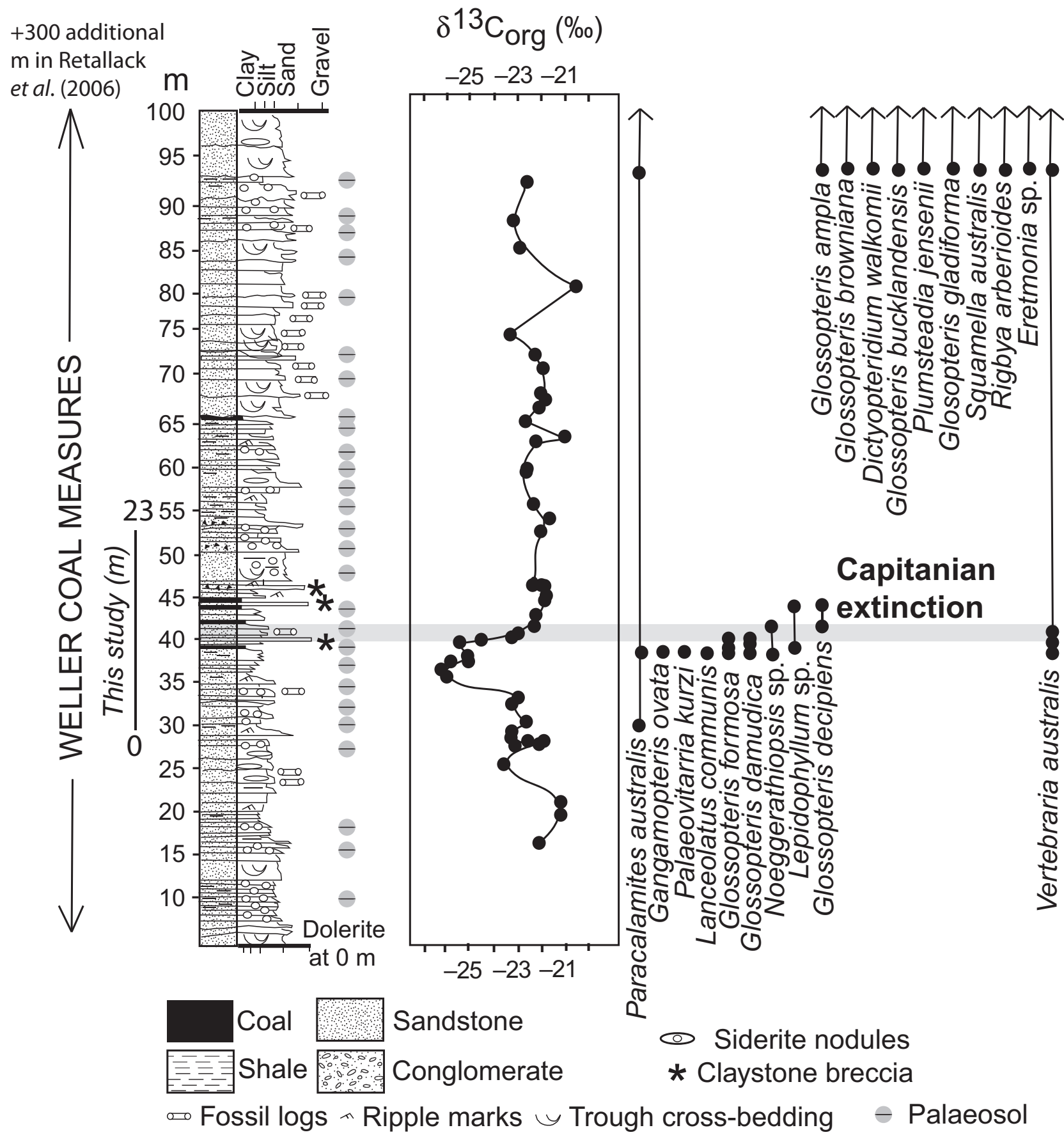

Fig. 2. Stratigraphy and carbon isotopes at Portal Mountain. Carbon isotope stratigraphy and plant biostratigraphy are shown, in addition to the stratigraphic positions of palaeosols, 'claystone breccia' horizons, fossil logs and other sedimentary features modified after Retallack et al. (2006). This study focuses on a $23 \mathrm{~m}$ section that spans roughly the 30 to $53 \mathrm{~m}$ levels in the studied stratigraphy of Retallack et al. (2006) from the same site. 


\section{Provenance}

Differences in provenance can be examined using a variety of different major and trace element ratios. For example, the $\mathrm{Ti} / \mathrm{Al}$ ratio is a useful indicator of source area differences because, while $\mathrm{Ti}$ content is highly variable in different
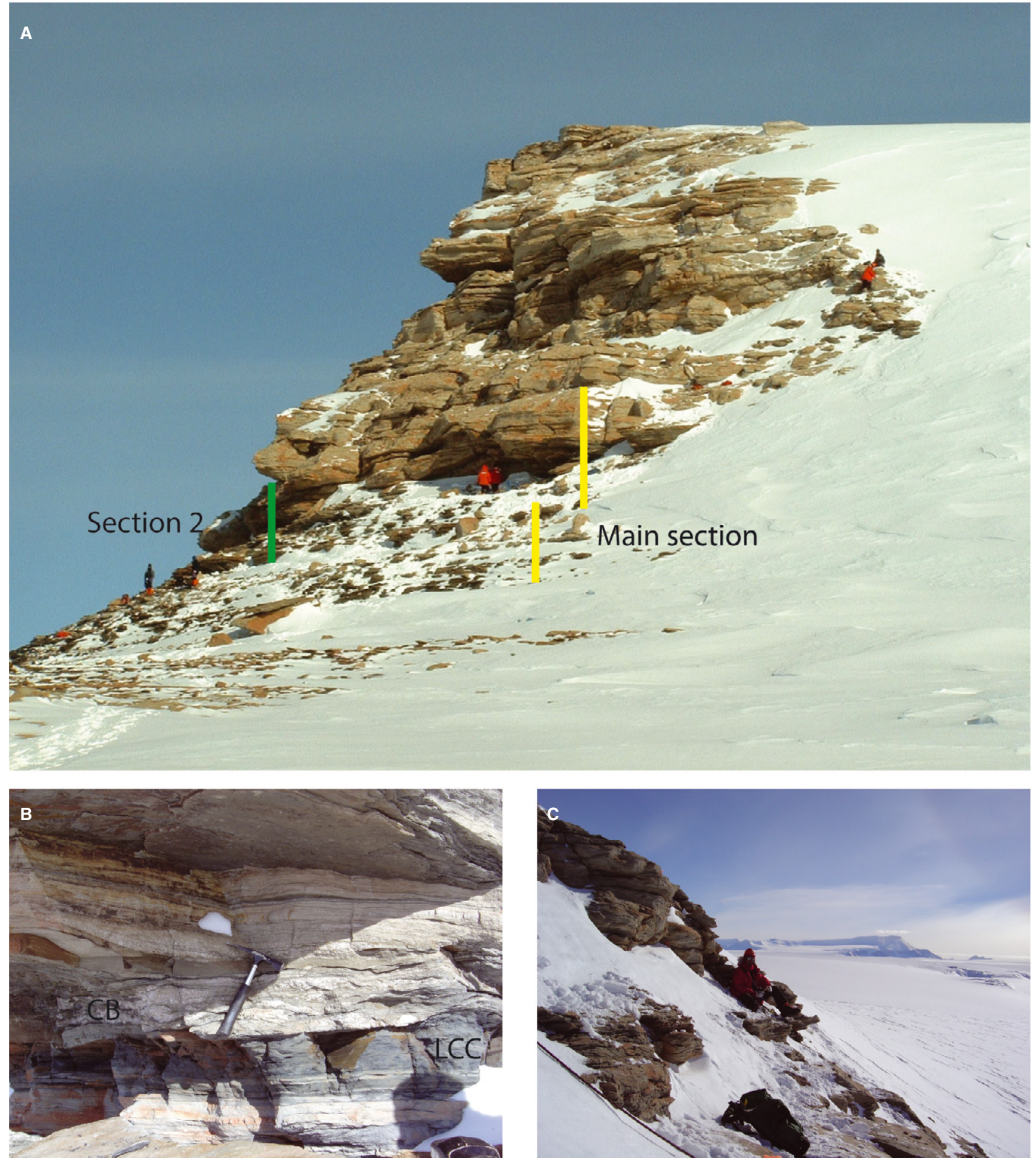

Fig. 3. Outcrop photographs. (A) Long-distance view of the focus interval for this study. Section 1 (yellow) is the 'long-section' and section 2 (green) is the secondary section to look at horizontal variability. Persons for scale are ca $1.8 \mathrm{~m}$ tall. (B) Close-up of the last Capitanian coal (LCC) and 'claystone breccia' (CB) identified by Retallack et al. (2006), at $c a 45 \mathrm{~m}$ in the overall section (Fig. 2). The rock hammer is $30 \mathrm{~cm}$ long. (C) Stacked, high-energy beds about the Capitanian extinction interval; backpack in foreground is $c a 75 \mathrm{~cm}$. 
rock types, Al content normally varies within a narrower range (Sheldon \& Tabor, 2009). It has been applied as a provenance tool to rocks spanning from the Precambrian (e.g. Driese et al., 2007; Mitchell \& Sheldon, 2009, 2010) through to the Cenozoic (e.g. Hamer et al., 2007). Similarly, the U/Th ratio has been used as an indicator of provenance (e.g. Sheldon, 2006a), in part because both elements are relatively immobile during oxidative weathering (e.g. van der Weijden \& van der Weijden, 1995; Pett-Ridge et al., 2007). Sheldon (2006a) also found that results using the REE ratio of $\mathrm{La} / \mathrm{Ce}$ to assess provenance matched results from the more widely applied $\mathrm{Ti} / \mathrm{Al}$, and suggested that it provides an additional means of assessing provenance.

\section{Weathering intensity}

A number of proxies have been developed to assess weathering intensity in palaeosols (reviewed in Sheldon \& Tabor, 2009), but the most widely applied is the chemical index of alteration (CIA; Nesbitt \& Young, 1982)

$$
\mathrm{CIA}=100 \times\left(\frac{m_{\mathrm{Al}}}{m_{\mathrm{Al}}+m_{\mathrm{Ca}}+m_{\mathrm{Na}}+m_{\mathrm{K}}}\right)
$$

where $m_{x}$ refers to the molar content of each of $\mathrm{Al}, \mathrm{Ca}, \mathrm{Na}$ and $\mathrm{K}$ in a given sample (Eqs 1, 3 and 4). The CIA was designed to look at the breakdown of feldspars to form clay minerals, and typically ranges from a value of $c a 40$ (unweathered basalt) to 100 (pure kaolinite). High values (i.e. more intensely weathered) can arise either as a function of climatic conditions (for example, higher temperatures lead to higher weathering rates) or as a function of long formation times, because even moderate climatic conditions can yield intensely weathered soils if they operate for a sufficient amount of time. Sheldon \& Tabor (2009) proposed a modified version of the CIA designed to assess temporal trends in weathering intensity:

$$
\Delta W=\mathrm{CIA}_{x}-\mu_{\mathrm{CIA}}
$$

where CIA $_{x}$ is the CIA value for a palaeosol B horizon and $\mu_{\text {CIA }}$ refers to the mean CIA value for a time series of palaeosol B horizons. The $\Delta W$ proxy was recently applied by Sheldon et al. (2012) to look at weathering changes across the Eocene-Oligocene transition, where additional a significant reduction was demonstrated in chemical weathering that occurred concomitantly with a drop in atmospheric $\mathrm{pCO}_{2}$ and by Retallack et al. (2011) who demonstrated significantly enhanced $\Delta W$ values in concert with increasing atmospheric $\mathrm{pCO}_{2}$. The $\Delta W$ proxy was also applied by Ohta et al. (2011) to characterize weathering intensity and palaeoclimatic changes associated with dinosaur evolution in China. Thus, the proxy appears to be a sensitive recorder of both increasing and decreasing intensity of chemical weathering.

\section{Pedogenesis}

The rates of many pedogenic processes are determined by climate, including salinization (accumulation of soluble salts):

$$
S=\frac{m_{\mathrm{K}}+m_{\mathrm{Na}}}{m_{\mathrm{Al}}}
$$

wherein soils forming under low mean annual temperature (MAT) regimes accumulate $\mathrm{K}$ and Na during pedogenesis, particularly in their A and B horizons (Sheldon et al., 2002). Thus, low $S$ values generally occur in warmer climates and higher $S$ values typically occur in cooler climates. Although that proxy is not applied here, calculated $S$ values from Eq. 3 may also be used to estimate palaeotemperature quantitatively via a somewhat weak empirical relation (e.g. Krause et al., 2010). Similarly, clay accumulates in soils as a function of temperature as well, where 'clayeyness' can be determined as follows:

$$
C=\frac{m_{\mathrm{Al}}}{m_{\mathrm{Si}}}
$$

because while $\mathrm{Si}$ is not typically very mobile during weathering, $\mathrm{Al}$ accumulates as weatherable minerals such as feldspars are transformed into clay minerals (Sheldon, 2006b). Thus, higher temperatures lead to higher $C$ values (e.g. Takeuchi et al., 2007). Similarly, some authors have used the molar ratio of $\mathrm{Ba}$ to $\mathrm{Sr}$ as a proxy for the degree of leaching during soil formation (e.g. Retallack, 2008; Kalinin \& Alekseev, 2011), which is broadly comparable to clay formation due to hydrolysis.

\section{RESULTS}

\section{Sedimentology and stratigraphy of Portal Mountain}

The Capitanian extinction interval is preserved at Portal Mountain as part of the Weller Coal 
Measures and is $40 \mathrm{~m}$ stratigraphically above the regionally extensive Ferrar Dolerite (Fig. 2). The Weller Coal Measures are dominated locally by sandstones and siltstones, with a notable increase in grain size across the Capitanian extinction (Fig. 3C). To summarize from Retallack et al. (2006), the extinction interval locally is recognized on the basis of: (i) a significant plant extinction (Fig. 2); (ii) an erosive 'claystone' breccia horizon (Fig. 3B; Retallack, 2005) accompanied by a change in fluvial style that is similar to the earliest Triassic Feather Conglomerate or age-equivalent Fremouw Formation (Collinson et al., 1994) found elsewhere in Antarctica (i.e. similar facies transitions at both Permian extinction levels); and (iii) a negative $\delta^{13} \mathrm{C}_{\text {org }}$ excursion of greater than $-4 \%$ (ca 20 to $35 \mathrm{~m}$ in Fig. 2), followed immediately by a return to a similar pre-excursion baseline value of $\mathrm{ca}-22 \%$. Stratigraphically above and below the boundary interval, there are sandy palaeosols with small, ellipsoidal siderite nodules, which are typically associated with strongly reducing conditions (e.g. Ludvigson et al., 1998). Siderite disappears in the boundary interval itself, but is considered authigenic throughout because there are syneresis cracks and some of the nodules have nucleated on root traces (Retallack et al., 2006). Most of the palaeosols in the boundary interval (Fig. 2) are similar to modern Aquents (waterlogged, weakly developed soils with some relict sedimentary structure and $\mathrm{A}-\mathrm{Bg}-\mathrm{C}$ horizonation; Retallack et al., 2006), whereas the Permian-Triassic transition elsewhere in Antarctica (Retallack et al., 2005) is characterized by coaly palaeosols (Histosols) that disappear at the Permian-Triassic extinction and are replaced by Aquents similar to Portal Mountain. As with Changhsingian-Gri- esbachian palaeosols, the Capitanian palaeosols are all characterized by evidence for gleying and locally reducing conditions (for example, green colour, siderite nodules) rather than welldrained, well-aerated conditions (for example, red colour, calcium carbonate nodules; Kraus \& Aslan, 1993; Sheldon, 2005).

\section{Major element geochemistry}

Titanium/aluminium ratios are essentially unchanged through the Capitanian extinction event (Fig. 4A), with the replicate Capitanian sections yielding identical mean values (Table 1). Values of Ti/Al less than $0 \cdot 1$, as in each of the three sets of data, are consistent with a sedimentary parent material (Sheldon \& Tabor, 2009).

The bulk chemical composition of both preextinction and post-extinction sedimentary rocks forms arrays when plotted against $\mathrm{SiO}_{2}$ content (Fig. 5A and B). While data from the replicate pre-extinction Capitanian sections typically plot together, the younger post-extinction Capitanian data show less overlap with the other data sets (Fig. 5). The $\mathrm{SiO}_{2}$ content of the younger Capitanian samples is typically higher (>75 wt\%) and spans a narrower range than older Capitanian samples. Chemical index of alteration values are negatively correlated with $\mathrm{SiO}_{2}$ content (Fig. 5C).

When CIA is plotted as a function of stratigraphic position instead, there is again considerable overlap between the replicate pre-extinction Capitanian sections and the younger Capitanian data, and there is no increase in CIA within the Capitanian as a whole (Fig. 6A; Table 1). While the $\Delta W$ values become more variable in the postextinction Capitanian than in the pre-extinction Capitanian, there is no evidence of an increasing
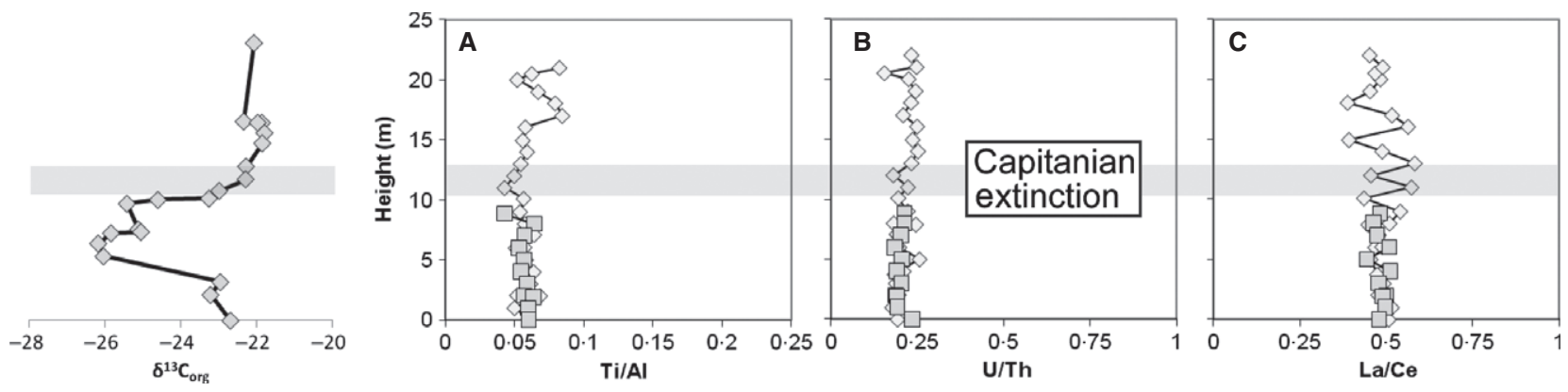

Fig. 4. Geochemical ratios for differentiating sedimentary provenance ratios. For reference, elemental ratios are plotted alongside the $\delta^{13} \mathrm{C}_{\mathrm{org}}$ excursion that defines the Capitanian extinction at Portal Mountain. Ratios plotted include: (A) Ti/Al; (B) U/Th and (C) La/Ce - each indicates a consistent sediment source for both pre-extinction and post-extinction sediments. 
Table 1. Comparison of mean geochemical ratios.

\begin{tabular}{|c|c|c|c|}
\hline Ratio & Pre-extinction I & Pre-extinction II & Post-extinction \\
\hline \multicolumn{4}{|l|}{ Provenance } \\
\hline $\mathrm{Ti} / \mathrm{Al}$ & $0.06(0.006)^{*}$ & $0.06(0.006)$ & $0.06(0.01)$ \\
\hline $\mathrm{La} / \mathrm{Ce}$ & $0.49(0.020)$ & $0.48(0.020)$ & $0.48(0 \cdot 06)$ \\
\hline U/Th & $0 \cdot 20(0 \cdot 020)$ & $0 \cdot 20(0 \cdot 010)$ & $0.22(0.03)$ \\
\hline \multicolumn{4}{|c|}{ Weathering intensity } \\
\hline CIA & $61 \cdot 40(2 \cdot 320)$ & $62 \cdot 60(2 \cdot 730)$ & $57 \cdot 6(4 \cdot 22)$ \\
\hline$\Delta W$ & $+1 \cdot 86(2 \cdot 300)$ & $+0.06(2.900)$ & $-1.99(4.20)$ \\
\hline $\mathrm{Ba} / \mathrm{Sr}$ & $1.92(0 \cdot 680)$ & $1.63(0 \cdot 710)$ & $1.97(0.79)$ \\
\hline \multicolumn{4}{|c|}{ Pedogenic processes } \\
\hline Salinization & $0 \cdot 29(0 \cdot 040)$ & $0 \cdot 28(0 \cdot 040)$ & $0.40(0.05)$ \\
\hline Clayeyness & $0 \cdot 13(0.030)$ & $0 \cdot 15(0.050)$ & $0.07(0.01)$ \\
\hline
\end{tabular}

${ }^{*}$ Values in the parentheses represent $1 \sigma$ uncertainty of the mean value.

$\Delta W$ value and, like the CIA, the mean value decreases upsection (Fig. 6B).

Molar ratios related to pedogenic processes give a coherent response during the Capitanian (Fig. 7; Table 1). The salinization and 'clayeyness' ratios are indistinguishable between the replicate pre-extinction Capitanian sections, and indicate a long-term secular trend upsection through the post-extinction Capitanian section, with a higher degree of salinization and a lower degree of 'clayeyness' upwards through the Capitanian, post-dating the extinction event.

\section{Trace and rare earth geochemistry}

Trace element ratios used to separate sediments of different provenance are plotted in Fig. 4B and $\mathrm{C}$. Both the U/Th and La/Ce ratios are indistinguishable between the replicate pre-extinction Capitanian sections and when compared to postextinction Capitanian values. This unchanging pattern matches the Ti/Al results (Fig. 3A; Table 1), which indicates an unchanging source area.

At the same time, the mean REE content is not constant (Fig. 8; Table 1). Each of the replicate pre-extinction Capitanian data sets is essentially identical, and the late Capitanian results are also similar for the heavy REE (HREE), but the late Capitanian samples are considerably less enriched relative to chondritic means in terms of their light REE (LREE) content. Light REE contents for the late Capitanian samples are $<1 / 2$ of the LREE contents of the two mid-Capitanian data sets.

There is a minor difference among redox-sensitive trace metals between the replicate mid-Capit- anian data sets and the late Capitanian data set (Fig. 9; Table 1). The late Capitanian samples are less U-rich, Ni-rich, Cu-rich, Eu-rich and Cr-rich than the mid-Capitanian replicate sample sets, which are indistinguishable (Fig. 10).

Although not plotted here, there is also no change in $\mathrm{Ba} / \mathrm{Sr}$ ratios through the Capitanian (Table 1). Values are generally similar to latest Permian sections elsewhere in Antarctica (Sheldon, 2006a).

\section{DISCUSSION AND INTERPRETATION}

\section{Provenance and weathering intensity results compared}

On the basis of both major and trace element geochemistry (Fig. 4), there is no significant difference in the provenance of the sediments across the Capitanian mass-extinction boundary at Portal Mountain, which is similar to what is observed across the end-Permian boundary at different sites (for example, Graphite Peak; Sheldon, 2006a; Table 1). Therefore, changes in the geochemical proxies for weathering intensity or the intensity of pedogenic processes must be a result of changing environmental or climatic variables. Major element proxies for weathering intensity (Fig. 6) do not indicate enhanced chemical weathering during the mid-Capitanian, immediately below the local plant extinction and claystone breccia, but the late Capitanian was a time of reduced weathering intensity. That result is confirmed by both trace element $(\mathrm{Ba} / \mathrm{Sr}$; Table 1) and REE comparisons. In particular, there is significantly less accumulation of REE 


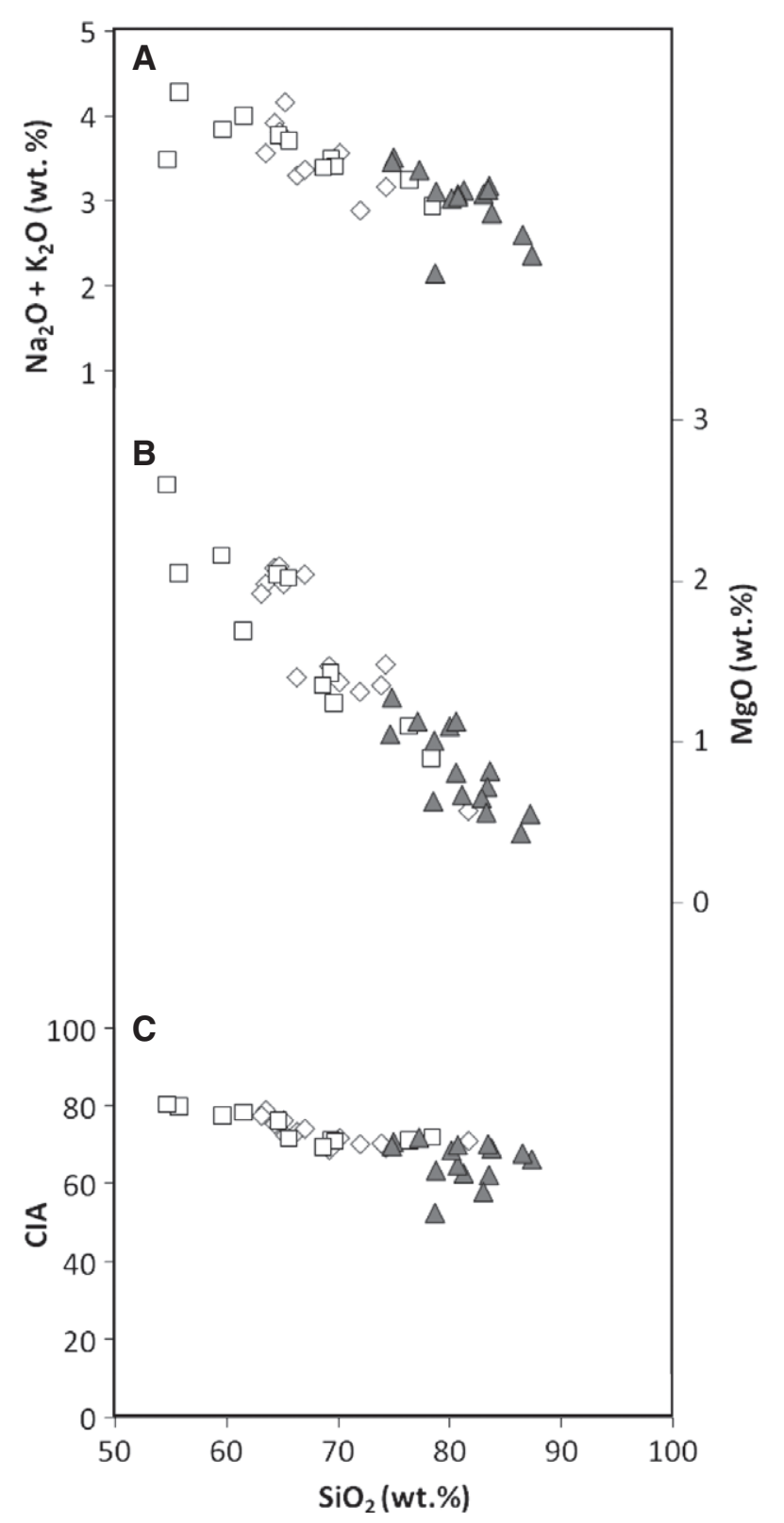

Fig. 5. Major element chemistry. Major elements (A) $\mathrm{Na}_{2} \mathrm{O}+\mathrm{K}_{2} \mathrm{O}$, (B) $\mathrm{MgO}$ and (C) CIA plotted against $\mathrm{SiO}_{2}$ content. Diamonds represent samples from the main pre-extinction section, squares are from the replicate pre-extinction section and triangles represent samples from the main post-extinction section.

overall and especially among the LREE in the late Capitanian samples relative to the mid-Capitanian ones. The solubility of REE and platinum group elements is typically low under the circum-neutral $\mathrm{pH}$ conditions found in most soils (Wimpenny et al., 2007), with some increase in solubility under more acidic conditions (Tyler, 2004). Because REEs accumulate as a function of either soil formation time (Zhang et al., 2007; Kahmann \& Driese, 2008) or of weathering intensity (Kahmann et al., 2008; Sheldon \& Tabor, 2009), the decline in REE accumulation could be simply a change in soil formation duration. However, given the relatively weak and uniform development of palaeosols both before and after the Capitanian extinction (Retallack et al., 2006), and given that both CIA and $\Delta W$ values decline above that, it is unlikely that the change in REE accumulation is due to changes in the duration of pedogenesis. Alternatively, the decrease in REE accumulation could represent an increase in soil $\mathrm{pH}$, which would, in turn, reduce REE solubility (Tyler, 2004). This latter possibility is reasonable given that at Portal Mountain, the sideritic palaeosols (Aquents; moderate $\mathrm{pH}$ ) preserved both before and after the Capitanian extinction can be contrasted with the peaty palaeosols (Histosols; acidic $\mathrm{pH}$ ) within the zone of negative carbon isotopic composition and decline to extinction of characteristic Middle Permian fossil plants. Thus, because a change in palaeosol parent material can be discounted (Fig. 3), the declining weathering intensity indicated by major element (Figs 6 and 7) and REE data (Fig. 8) indicates a significant local change in weathering intensity across the Capitanian mass extinction.

\section{Redox changes across the Capitanian extinction}

There is a systematic shift in the concentration of redox-sensitive elements during the Capitanian (Fig. 10) towards lower values $(\mathrm{Cu}, \mathrm{Cr}, \mathrm{Ni}, \mathrm{U}, \mathrm{Ce}$ and $\mathrm{Eu}$ ). While the differences between the midCapitanian replicate sample sets and the late Capitanian samples are typically $c a 1 \sigma$, the basic pattern holds for all of the elements that were considered. Within modern soils, the distribution of redox-sensitive metals is usually a function of local environmental controls rather than of climatic differences among sites (Gueniot et al., 1988a). For example, while U does not accumulate in well-drained, well-aerated soils (Gueniot et al., 1988a) or palaeosols (Sheldon, 2005), it commonly accumulates in waterlogged, hydromorphic soils (Gueniot et al., 1988b) and palaeosols (Sheldon, 2006a). Similarly, $\mathrm{Ce}^{4+}$ is insoluble, whereas $\mathrm{Ce}^{3+}$ is soluble under reducing conditions.

Stratigraphically speaking, the shift in redox-sensitive element concentration occurs concurrently with the mid-Capitanian isotopic excursion (Fig. 10B and C), and a new lower baseline is 

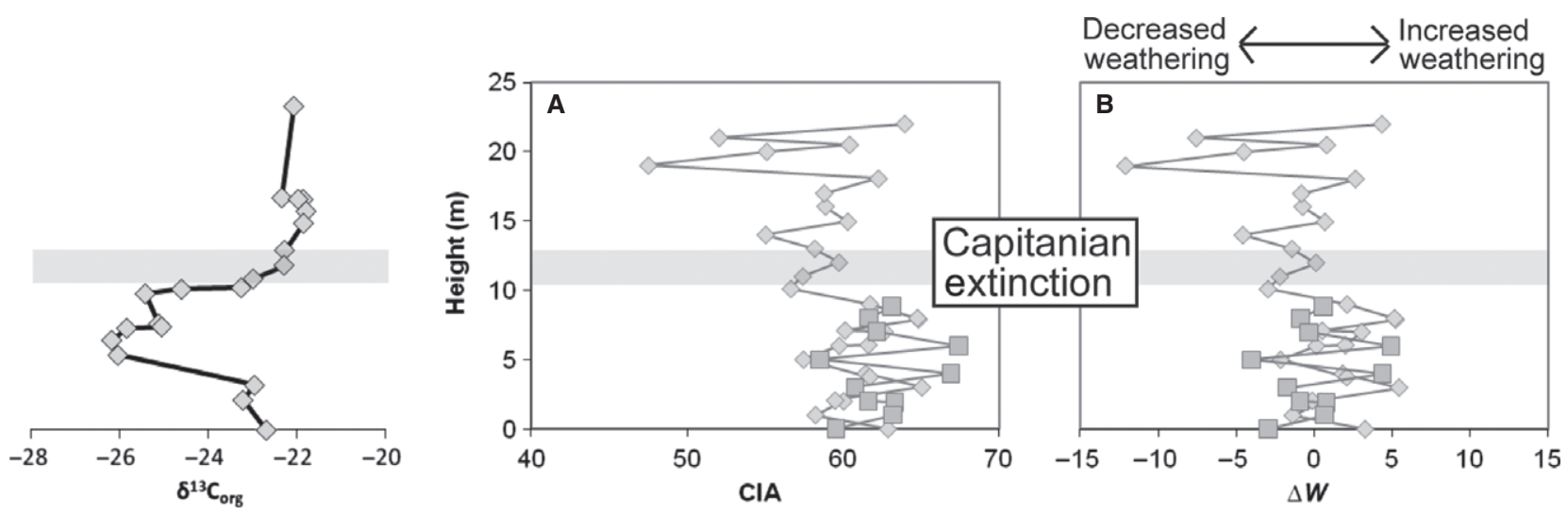

Fig. 6. CIA and $\Delta W$ as a function of stratigraphy. For reference, elemental ratios are plotted alongside the $\delta^{13} \mathrm{C}_{\mathrm{org}}$ excursion that defines the Capitanian extinction at Portal Mountain. Weathering intensity is given as (A) CIA and (B) $\Delta W$, plotted as function of stratigraphic position. Diamonds represent samples from the main pre-extinction section, squares are from the replicate pre-extinction section and triangles represent samples from the main postextinction section.
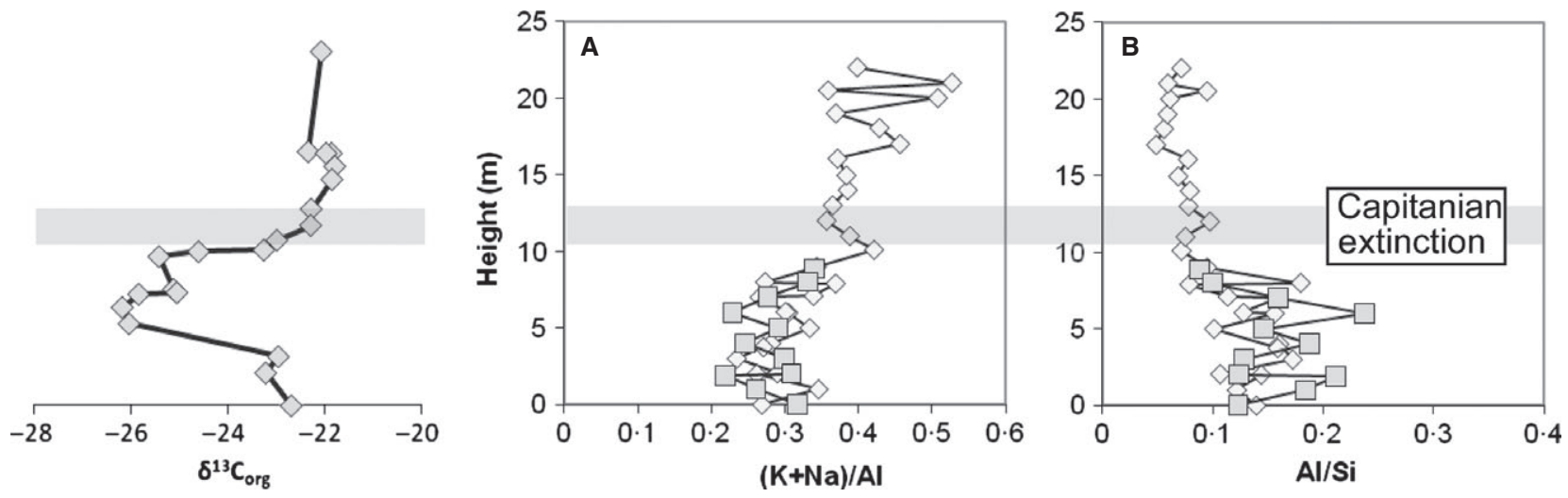

Fig. 7. Salinization and 'clayeyness' as a function of stratigraphy. For reference, elemental ratios are plotted alongside the $\delta^{13} \mathrm{C}_{\text {org }}$ excursion that defines the Capitanian extinction at Portal Mountain. Pedogenic processes (A) salinization and (B) 'clayeyness' are plotted as a function of stratigraphic position. Diamonds represent samples from the main pre-extinction section, squares are from the replicate pre-extinction section and triangles represent samples from the main post-extinction section.

established by the late Capitanian. Unlike the $\delta^{13} \mathrm{C}$ shift during the mid-Capitanian extinction, which rebounds back to its prior baseline, the shift in redox elements persists through the rest of the record (Fig. 10B and C).

\section{Capitanian climate change?}

Although quantitative climofunctions have not been used to reconstruct precise mean annual precipitation (MAP) or mean annual temperature (MAT) values, many of the proxy relations described above are also correlated with climate. For example, both salinization (Sheldon et al., 2002) and 'clayeyness' (Sheldon, 2006b) are related to MAT and a slightly modified version of CIA (Eq. 1) is strongly correlated with MAP. However, the quantitative proxy relations were all calibrated using well-drained modern soils (i.e. not waterlogged) so, while the relations may apply quantitatively, the more conservative approach of assuming that the vectors of change will match with currently derived empirical proxies even if the exact quantitative relation will not, has been taken. Salinization (Fig. 7B) is inversely related to MAT for modern soils (Sheldon et al., 2002); thus, the declining salinization ratios across the end-Guadalupian extinction event are consistent with declining MAT. Similarly, for weakly developed soils, 'clayey- 

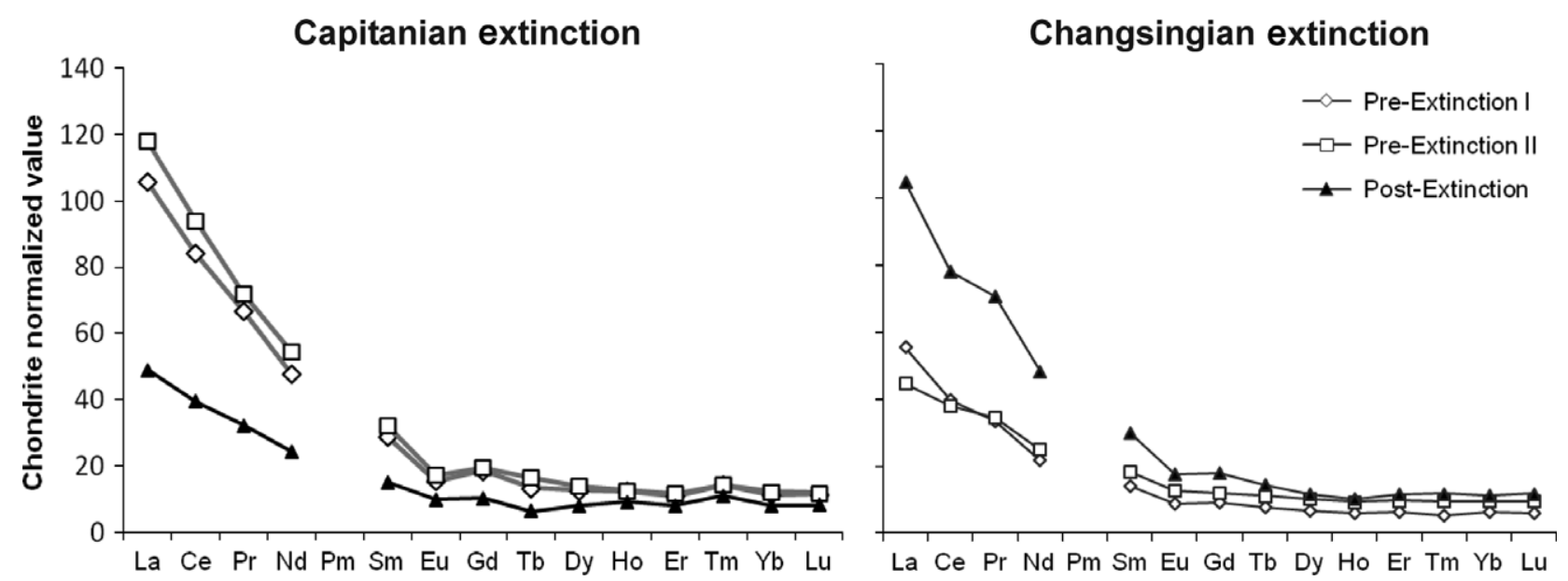

Fig. 8. Chondrite normalized REE as a function of time. Temporal mean REE element data are plotted normalized to chondritic data from Nakamura (1974) and indicate declining rather than increasing weathering intensity across the Capitanian extinction, whereas increasing weathering intensity is indicated for the Changhsingian extinction. Data for the Capitanian event are in the Data Repository; data for the Changhsingian event are from Sheldon (2006a).
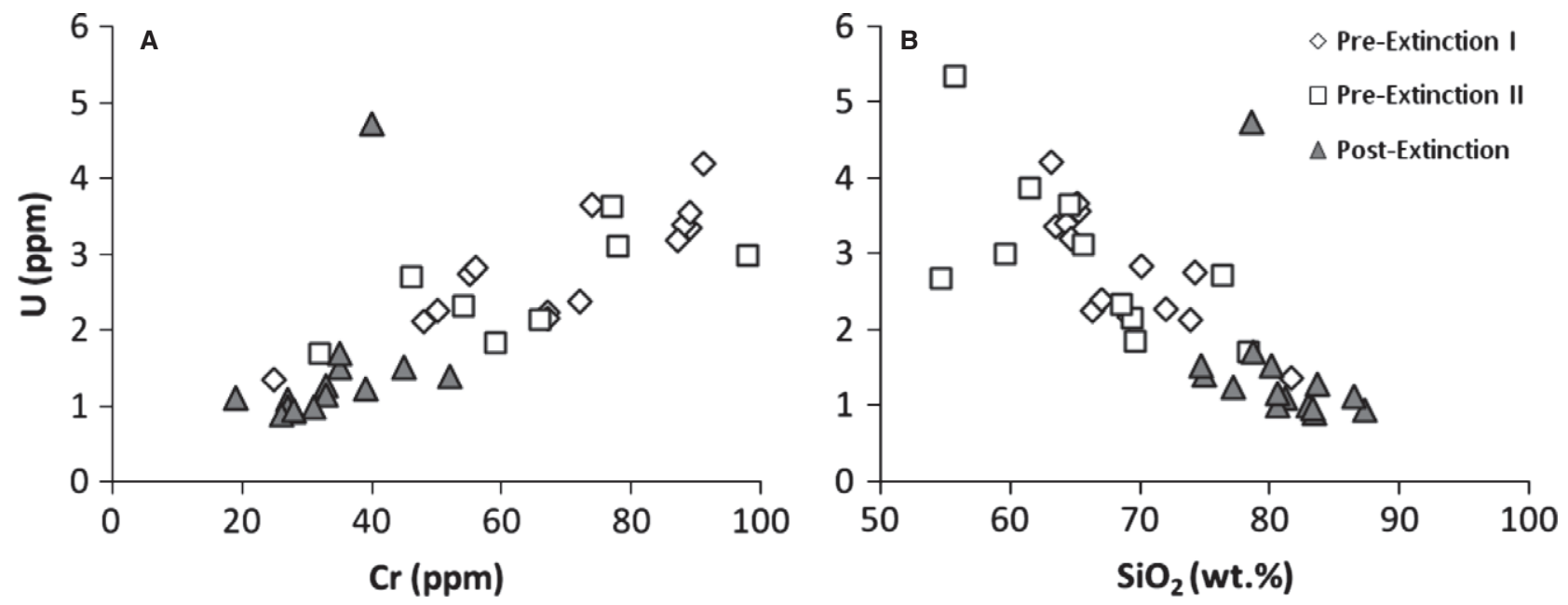

Fig. 9. Redox-sensitive trace elements. Uranium is plotted against (A) $\mathrm{Cr}$ and (B) $\mathrm{SiO}_{2}$. In general, there is little overlap between the pre-extinction and post-extinction sample sets in either plot, and the pre-extinction samples are more U-rich than the post-extinction ones.

ness' is linearly related to MAT, so the 'clayeyness' results are also consistent with declining MAT during the mid-Capitanian extinction event. The modest decrease in CIA across the mid-Capitanian extinction event was probably caused in part by a reduction in MAP, but perhaps the more striking feature is the increased range of $\Delta W$ values in the late Capitanian that indicates more variable weathering conditions and, possibly, more variable palaeoprecipitation conditions. Such variation in $\Delta W$, MAT and MAP has also been found in better drained and better developed palaeosols in the late Capitanian of the Sydney Basin, Australia (Retallack et al., 2011).

\section{Comparison with other terrestrial Capitanian records}

Stevens et al. (2011) described three distinct plant turnover events, with the middle event coincident with the marine Capitanian extinction, and the youngest event post-dating the main Emeishan large igneous province (LIP). 

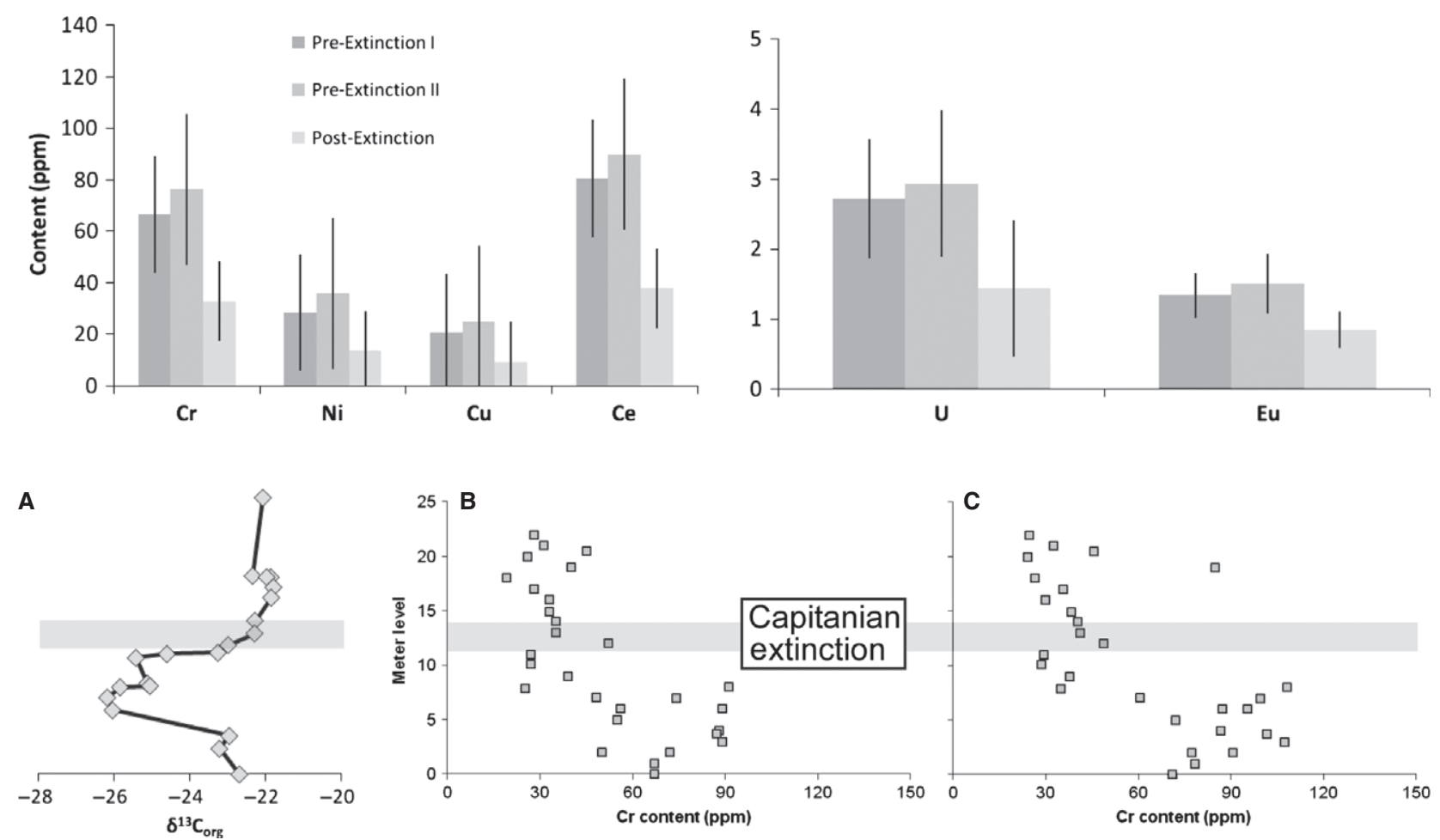

Fig. 10. Redox-sensitive trace elements as a function of time. (A) Error bars for each of the trace elements are $\pm 1 \sigma$. For $\mathrm{Cr}, \mathrm{Ni}, \mathrm{Cu}$ and $\mathrm{Ce}$, there is no overlap between the $1 \sigma$ error windows of the pre-Capitanian and post-Capitanian extinction sample sets; for $\mathrm{U}$ and for $\mathrm{Eu}$, the pre-extinction means are higher $(c a 2 \times)$, but the error windows overlap between the pre-Capitanian and post-Capitanian extinction sample sets because those elements are somewhat more variable and of lower overall abundance than $\mathrm{Cr}$, $\mathrm{Ni}$ and $\mathrm{Cu}$. For reference, elemental contents are plotted alongside the $\delta^{13} \mathrm{C}_{\text {org }}$ excursion that defines the Capitanian extinction at Portal Mountain where both (B) $\mathrm{Cr}$ and (C) Ce abundances shift to a lower baseline concurrently with the isotopic shift that marks the end of the Capitanian.

Similarly, Bond et al. (2010) recently reviewed marine and continental fossil records of the Capitanian mass extinction from a well-dated section in China, concluding that while the marine extinction event was clearly temporally associated with the Emeishan LIP (Wignall et al., 2009), the plant mass extinction may have postdated the main eruptive phase. Those authors also note that the characteristic negative carbon excursion associated with the Capitanian extinction is not synchronous with the apparent extinction level, which is also noted for the continental Antarctic record in the present study (Fig. 2). The magnitude of the middle event in China described by Stevens et al. (2011) is similar to the Capitanian records in Antarctica and South Africa (Retallack et al., 2006), although the overall diversity was much higher in China than in Antarctica, and the South African record is based entirely on pollen. Thus, although one possibility is that there were more plant turnover events in China than at the other sites, a more likely sce- nario is that China records a more complete continental plant record than the other sites, either due to taphonomic differences (for example, South Africa) or to overall biodiversity gradients comparable to modern ecosystems with lower diversity nearer to the poles (for example, Antarctica) than at lower palaeolatitudes.

There are relatively few continental Capitanian extinction event palaeosol records, and most represent relatively high-palaeolatitude Gondwanan sites. In general, the $\delta^{13} \mathrm{C}_{\text {org }}$ responses at those sites can be broken down into two categories: (i) moderate negative (lesser than $-3 \%$ ) excursions, as in Morondava, Madagascar (de Wit et al., 2002) and Muswellbrook, Australia (Compston, 1960; Retallack et al., 2011); and (ii) large negative (greater than $-3 \%$ ) excursions as in Graphite Peak, Antarctica (Krull \& Retallack, 2000), Raniganj, India (de Wit et al., 2002), Eddystone, Australia (Morante, 1996) and Portal Mountain, Antarctica (this study; Retallack et al., 2006). Generally speaking, as with the Late Permian 
mass-extinction event, the magnitude of the $\delta^{13} \mathrm{C}_{\text {org }}$ isotopic excursion is larger at higher palaeolatitude sites (Retallack \& Krull, 2006). However, with a dearth of mid-latitude and lowlatitude continental sites, this pattern may or may not hold up to future scrutiny. Ongoing work in Niger (Tabor et al., 2011), China (Yang et al., 2010) and Spain (De la Horra et al., 2012) may eventually allow for the latitudinal variability in $\delta^{13} \mathrm{C}_{\text {org }}$ to be addressed; but, at present, age control is poor in Niger and Spain (De la Horra et al., 2012), and work in China is still at a relatively early stage, but shows promise given a high degree of cyclicity among the continental deposits and a number of new U-Th-Pb ages (Yang et al., 2010). Nonetheless, a negative carbon isotopic excursion is a robust feature in both marine and continental records, and organic matter and carbonate records (table 1 of Retallack et al., 2006).

Retallack et al. (2006) made a detailed comparison between the palaeosols from Portal Mountain, Antarctica (this study), and from the Karoo Basin, South Africa, and found a number of additional similarities including a 'spike' of lycopsids, fungi, and algae, soil erosion horizons (claystone breccias in his parlance), soil stagnation, evidence for a greenhouse climate shift and a shift to braided stream deposits (Fig. 2). The similarities between those sites led the authors to suggest a global cause for the observed changes at both the high-palaeolatitude (Antarctica) and the low-palaeolatitude (South Africa) sites. The new geochemical results here support the idea of soil stagnation (Figs 9 and 10; siderite nodules present throughout both sections), but do not support a shift to a greenhouse climatic event beyond the resolution of the proxies employed here (i.e. while modest warming undetectable by the proxies used herein cannot be ruled out, a highmagnitude warming event can be). Indeed, the declining chemical weathering (Figs 6 and 8) and lessening of some temperature-dependent pedogenic processes such as clay formation/ 'clayeyness' and increase of others such as salinization are all consistent with a cooling rather than warming climate.

\section{Comparison with marine Capitanian records}

Capitanian marine turnover was first recognized in foraminifera (Jin et al., 1994; Stanley \& Yang, 1994), before subsequent workers found similar losses among dinocephalian reptiles (Lucas,
2009) and other continental organisms (Retallack et al., 2006), and among a variety of marine invertebrates including ammonoids, bivalves, brachiopods, bryozoans and corals (Clapham et al., 2009; Bond et al., 2010). Although the pace of the extinction event continues to be debated (e.g. Clapham et al. 2009 vs. Bond et al. 2010), there is general consensus about the magnitude of losses and that the extinction event is more a product of reduced originations rather than increased extinctions. Among 'typical' extinction causal mechanisms, Bond et al. (2010) argue against sea-level fall or climatic cooling because the major sequence boundary post-dates the Capitanian extinction and the major positive $\delta^{13} \mathrm{C}$ 'Kamura Event' (Isozaki et al., 2007) also post-dates the extinction event in the global stratotype section in China, and against marine anoxia because fully oxygenated conditions appear to have been present at the extinction level (Wignall et al., 2010). While it is generally difficult to compare marine and continental records directly, large redox changes are often recorded by both types of depositional settings. For example, both marine and continental settings record significant reducing conditions in the earliest Triassic (Sheldon, 2006a), whereas for the Capitanian extinction, neither marine (Wignall et al., 2010) nor continental (Fig. 9) records indicate a significant redox shift, suggesting that both types of settings are recording similar global conditions.

\section{Comparison with the Permian-Triassic extinction event}

While there are some significant similarities (Table 2) between Gondwanan records of continental Middle and Late Permian mass-extinction events, including a high level of vertebrate and plant extinctions, a shift in fluvial depositional style from meandering to braided streams, a large negative $\delta^{13} \mathrm{C}$ anomaly and evidence for a soil erosion crisis, there are also significant differences. In particular, while an abrupt series of warming events coincide with the Late Permian mass extinction (Berner, 2002; Kidder \& Worsley, 2003; Sheldon, 2006a; Retallack \& Jahren, 2008; Algeo et al., 2011a,b), the new record presented herein is consistent instead with unchanging, or even cooling conditions (Figs 7 and 8). Enhanced chemical weathering, REE accumulation (Fig. 8) and changes to pedogenic process intensity were all observed in the latest Changhsingian of Antarctica (Sheldon, 2006a), 
whereas the latest Capitanian is characterized by declining chemical weathering (Fig. 6), reduced REE accumulation (Fig. 8) and changes in pedogenic process intensity (Fig. 7) that are consistent with cooling rather than warming conditions, and which cannot be explained as reflecting changing source terrain (Fig. 4). Furthermore, while there is extensive evidence for a substantial redox shift during the Late Permian to more chemically reducing conditions in soils and perhaps the atmosphere (Figures S1 and S2; e.g. Sheldon \& Retallack, 2002; Huey \& Ward, 2005; Sheldon, 2006a) that are matched by marine records (Knoll et al., 1996; Kidder \& Worsley, 2003), results from Portal Mountain are not consistent with the Late Permian in that they indicate slightly more oxidized conditions (Figs 9 and 10), or with marine records that indicate a more mixed response with both anoxic (Weidlich, 2002; Clapham et al., 2009) and oxic (Wignall et al., 2009; Bond et al., 2010) conditions prevailing locally. Thus, on the basis of substantial differences in the climatic and redox responses of continental records of Changhsingian and Capitanian mass extinctions, the two events were either of different magnitude and duration or did not share a common causal mechanism.

Table 2. Comparison of Changhsingian and Capitanian events.

\begin{tabular}{lll}
\hline Environmental change & $\begin{array}{l}\text { Capita- } \\
\text { nian }\end{array}$ & $\begin{array}{l}\text { Changh- } \\
\text { singian }\end{array}$ \\
\hline $\begin{array}{l}\text { Similarities } \\
\text { Negative } \delta^{13} \mathrm{C} \text { excursion }\end{array}$ & Yes & Yes \\
$\begin{array}{l}\text { Change in fluvial style from } \\
\text { dominantly meandering to } \\
\text { dominantly braided }\end{array}$ & Yes & Yes \\
$\begin{array}{l}\text { Change in sediment provenance } \\
\text { Shift towards reducing conditions } \\
\text { across boundary (Cu, Cr, Ni, }\end{array}$ & Yes & Yes \\
$\begin{array}{l}\text { Ce shifts) } \\
\text { Differences }\end{array}$ & \\
$\begin{array}{l}\text { Increase in weathering } \\
\text { intensity (CIA, } \Delta W \text { ) }\end{array}$ & No & Yes \\
$\begin{array}{l}\left.\text { Increase in leaching ( } \sum \mathrm{REE}, \mathrm{Ba} / \mathrm{Sr}\right) \\
\text { Greenhouse climate shift }\end{array}$ & No & Yes \\
$\begin{array}{l}\text { Berthierine as reduced Fe-phase* } \\
\text { Siderite as reduced Fe-phase* }\end{array}$ & No & Yes \\
& Yes & No \\
\hline
\end{tabular}

*At high-latitude continental Gondwanan sites.

\section{Capitanian extinction causal mechanism}

A variety of common causal mechanisms have been invoked for the Capitanian and Changhsingian extinctions, including ocean anoxia, LIP emplacement, global climate change (warming) and methane outbursts either from marine sources or from coal-beds. As noted above, ocean anoxia can be excluded for the Capitanian extinction and it is very difficult to envision a scenario in which continental plant and animal mass extinctions could possibly be caused by marine anoxia, so it is probably an effect rather than a cause for the Changhsingian extinction as well. Both LIP emplacement and methane outbursts could potentially cause global warming, depending on the composition of the degassed gases associated with the LIP (for example, dominantly $\mathrm{H}_{2} \mathrm{O}$ and $\mathrm{CO}_{2}$, low $\mathrm{SO}_{2}$ ). At the same time, it is very difficult to trigger a large negative carbon isotopic anomaly in either marine or continental settings without a significant input of isotopically depleted carbon from methane (Berner, 2002), but it is not always possible to deconvolve whether methane release was a cause or an effect of some other climatic warming mechanism (Sheldon, 2006a). Retallack \& Jahren (2008) linked methane release to coal-bed intrusion by dykes associated with LIPs and suggested that it could be a common causal mechanism for both the Capitanian and Changhsingian extinction events, possibly due to a catastrophic drop in atmospheric oxygen that may have been responsible for continental vertebrate extinctions. However, both marine records (Bond et al., 2010) and the new Antarctic Capitanian record indicate relatively stable climatic conditions without evidence for extreme warming, as recorded by the Changhsingian extinction in both marine and continental settings (Berner, 2002; Kidder \& Worsley, 2003; Sheldon, 2006a; Retallack \& Jahren, 2008; Algeo et al., 2011a,b), and indicate no significant redox change, even though the depositional setting is identical for the Changhsingian and Capitanian records from Antarctica. Similarly, the Changhsingian mass extinction is characterized by a significant increase in chemical weathering due to warm/ wetter climatic conditions (Sheldon, 2006a; Algeo \& Twitchett, 2010; Algeo et al., 2011a,b; Retallack et al., 2011), but no similar increase in chemical weathering intensity is recorded for the Capitanian (Figs 6 and 8). Thus, while the LIPtriggered coal-bed methane hypothesis is wellsupported for the Changhsingian extinction (e.g. 
Grasby et al., 2011; Ogden \& Sleep, 2012), it is not well-supported for the Capitanian extinction. At the same time, interbedded marine limestones and Emeishan LIP basalt flows strongly suggest a causal link between the Capitanian mass extinction and the Emeishan LIP (Wignall et al., 2009), and plant extinction events locally in China also correlate temporally with the Emeishan LIP. Therefore, the differences in the geochemical signatures and magnitude of the two extinction events could either reflect a lack of coal-bed methane release during the Capitanian, or that the volcanic emissions associated with the Emeishan LIP were relatively richer in $\mathrm{SO}_{2}$ (antigreenhouse gas), less $\mathrm{CO}_{2}$-rich or involved much lower total gas fluxes. It is difficult to discern between these latter possibilities, but it is clear that the Emeishan LIP caused local (Wignall et al., 2009) and possibly global environmental impacts as well.

\section{CONCLUSIONS}

New high-resolution continental records of palaeosol geochemistry spanning the Middle Permian (Capitanian) mass-extinction event in Antarctica were compiled and compared to continental records of palaeosol geochemistry from the Late Permian (Changhsingian) mass extinction to look for evidence of similarities that would indicate a common causal mechanism. On the basis of major and trace element data, the protolith for the pre-extinction and post-extinction palaeosols is the same, which means that any changes in other geochemical proxies may be related to environmental or climatic shifts. Both major and trace element proxies indicate declining chemical weathering intensity throughout the Capitanian extinction, which is in sharp contrast to proxies of end-Permian weathering intensity that indicate enhanced weathering intensity. Proxies related to climatic change indicate no change or a slight cooling during and after the Middle Permian event, whereas the latest Permian to early Triassic saw elevated and continuing greenhouse crises (Retallack et al., 2011). Although the high-latitude Gondwanan records of both events indicate a significant redox shift, the sign of that shift is opposite in Antarctica where the Capitanian extinction indicates more oxidizing conditions and the Changhsingian extinction indicates more reducing conditions. Thus, on the basis of substantially different (or diametrically opposed) results for weathering intensity, climatic conditions and soil redox, it can be concluded that climatic and environmental drivers were fundamentally different for the two extinction events.

\section{ACKNOWLEDGEMENTS}

The authors would like to acknowledge support from the NSF (OPP0230086) and assistance in the field from Carolyn Phillips, Shaun Norman, Christine Metzger and Luann Becker. Paul Gabraiel performed the ICP analyses at Royal Holloway. One anonymous reviewer and reviewer Steve Driese, along with Associate Editor Adrian Immenhauser, are thanked for constructive comments that improved the original manuscript.

\section{REFERENCES}

Algeo, T.J. and Twitchett, R.J. (2010) Anomalous Early Triassic sediment fluxes due to elevated weathering rtes and their biological consequences. Geology, 38, 10231026.

Algeo, T.J., Chen, Z.Q., Fraiser, M.L. and Twitchett, R.J. (2011a) Terrestrial-marine teleconnections in the collapse and rebuilding of Early Triassic marine ecosystems. Palaeogeogr. Palaeoclimatol. Palaeoecol., 308, 1-11.

Algeo, T.J., Kuwahara, K., Sano, H., Bates, S., Lyons, T., Elswick, E., Hinnov, L., Ellwood, B., Moser, J. and Maynard, J.B. (2011b) Spatial variation in sediment fluxes, redox conditions, and productivity in the Permian-Triassic Panthalassic Ocean. Palaeogeogr. Palaeoclimatol. Palaeoecol., 308, 65-83. doi:10.1016/j.palaeo.2010.07.007

Askin, R.A. (1997) Permian palynomorphs for southern Victoria Land, Antarctica. Antarct. J. US, 30, 47-48.

Berner, R.A. (2002) Examination of hypotheses for the Permo-Triassic boundary extinction by carbon cycle modeling. Proc. Natl Acad. Sci., 99, 4172-4177.

Bond, D.P.G. and Wignall, P.B. (2009) Latitudinal selectivity of foraminifer extinctions during the Late Guadalupian crisis. Paleobiology, 35, 465-483.

Bond, D.P.G., Hilton, J., Wignall, P.B., Ali, J.R., Stevens, L.G., Sun., Y. and Lai, X. (2010) The Middle Permian (Capitanian) mass extinction on land and in the oceans. Earth Sci. Rev., 102, 100-116.

Chen, Z.-Q. and Benton, M.J. (2012) The timing and pattern of biotic recovery following the end-Permian mass extinction. Nat. Geosci., 5, 375-383.

Clapham, M.E., Shen, S.-Z. and Bottjer, D.J. (2009) The double mass extinction revisited: reassessing the severity, selectivity, and causes of the end-Guadalupian biotic crisis (Late Permian). Paleobiology, 35, 32-50.

Collinson, J.W., Isbell, J.L., Elliot, D.H., Miller, M.F., Miller, J.M.G. and Veevers, J.J. (1994) Permian-Triassic Transantarctic basin. In: Permian-Triassic Pangean Basins and Foldbelts Along the Panthalassan Margin of Gondwanaland (Eds J.J. Veevers and C.M. Powell), Geol. Soc. Am. Mem., 184, 173-222. 
Compston, W. (1960) The carbon isotope composition of certain marine invertebrates and coals from the Australian Permian. Geochim. Cosmochim. Acta, 18, 1-22.

De la Horra, R., Galan-Abellan, A.B., Lopez-Gomez, J., Sheldon, N.D., Barrenechea, J.F., Luque, F.J., Arche, A. and Benito, M.I. (2012) Paleoecological and paleoenvironmental changes during the continental Middle-Late Permian transition at the SE Iberian Ranges, Spain. Global Planet. Change, 94-95, 46-61.

Driese, S.G., Medaris, G., Jr, Ren, M., Runkel, A.C. and Langford, R.P. (2007) Differentiating pedogenesis from diagenesis in early terrestrial paleoweathering surfaces formed on granitic composition parent materials. J. Geol., 115, 387-406.

Erwin, D.H., Bowring, S.A. and Jin, Y.-G. (2002). EndPermian mass-extinctions: a review. In: Catastrophic Events and Mass Extinctions: Impacts and Beyond (Eds C. Koeberl and K.G. MacLeod), Geol. Soc. Am. Spec. Pap., 356, 353-383.

Farabee, M.J., Taylor, E.L. and Taylor, T.N. (1990) Correlation of Permian and Triassic palynomorph assemblages from the central Transantarctic Mountains, Antarctica. Rev. Palaeobot. Palynol., 65, 257-265.

Farabee, M.J., Taylor, E.L. and Taylor, T.N. (1991) Late Permian palynomorphs from the Buckley Formation, central Transantarctic Mountains, Antarctica. Rev. Palaeobot. Palynol., 69, 353-368.

Fio, K., Spangenberg, J.E., Vlahović, I., Sremac, J., Velić, I. and Mrinjek, E. (2010) Stable isotope and trace element stratigraphy across the Permian-Triassic transition: a redefinition of the boundary in the Velebit Mountain, Crotia. Chem. Geol., 278, 38-57.

Grasby, S.E., Sanei, H. and Beauchamp, B. (2011) Catastrophic dispersion of coal fly ash into oceans during the latest Permian extinction. Nat. Geosci., 4, 104-107.

Gueniot, G., Munier-Lamy, C. and Berthelin, J. (1988a) Geochemical behavior of uranium in soils, part I. Influence of pedogenetic processes on the distribution in aerated soils. J. Geochem. Explor., 31, 21-37.

Gueniot, G., Munier-Lamy, C. and Berthelin, J. (1988b) Geochemical behavior of uranium in soils, part II. Distribution of uranium in hydromorphic soils and soil sequences. Applications for surficial prospecting. $J$. Geochem. Explor., 31, 39-55.

Hamer, J.M.M., Sheldon, N.D., Nichols, G.J. and Collinson, M.E. (2007) Late Oligocene - Early Miocene Palaeosols of Distal Fluvial Systems, Ebro Basin, Spain. Palaeogeogr. Palaeoclimatol. Palaeoecol., 247, 220-235.

Huey, R.B. and Ward, P.D. (2005) Hypoxia, global warming and terrestrial Late Permian extinctions. Science, 308, 398-401.

Irmis, R.B. and Whiteside, J.H. (2012) Delayed recovery of non-marne tetrapods after the end-Permian mass extinction tracks global carbon cycle. Proc. R. Soc. B Biol. Sci., 279, 1310-1318.

Isbell, J.L. and Askin, R.A. (1999) Comment: search for evidence of impact at the Permian-Triassic boundary in Antarctica and Australia. Geology, 27, 859.

Isbell, J.L. and Cuneo, N.R. (1996) Depositional framework of Permian coal-bearing strata, southern Victoria Land, Antarctica. Palaeogeogr. Palaeoclimatol. Palaeoecol., 125, 217-238.

Isozaki, Y., Kawahata, H. and Ota, A. (2007) A unique carbon isotope record across the Guadalupian-Lopingian (Middle-Upper Permian) boundary in mid-oceanic paleo- atoll carbonates: the high-productivity "Kamura Event" and its collapse in Panthalassa. Global Planet. Change, 55, 21-38.

Jin, Y-G., Zhang, J. and Shang, Q-H. (1994) Two phases of the end-Permian mass extinction. In: Pangea: Global Environments and Resources (Eds A.F. Embry, B. Beauchamp and D.J. Glass), Can. Soc. Petrol. Geol. Mem., 17, 813-822.

Jin, Y.-G., Wang, Y., Wang, W., Sheng, Q., Cao, C.-Q. and Erwin, D.H. (2000) Pattern of marine mass extinction across the Permian-Triassic boundary in south China. Science, 289, 432-436.

Kahmann, J.A. and Driese, S.G. (2008) Paleopedology and geochemistry of the Late Mississippian (Chesterian) Pennington Formation paleosols at Pound Gap, Kentucky, USA: implications for high-frequency climate variations. Palaeogeogr. Palaeoclimatol. Palaeoecol., 259, 357-381.

Kahmann, J.A., Seaman, J., III and Driese, S.G. (2008) Evaluating trace elements as paleoclimatic indicators: multivariate statistical analysis of late Mississippian Pennington Formation paleosols, Kentucky, USA. J. Geol., 116, 254-268.

Kalinin, P.I. and Alekseev, A.O. (2011) Geochemical characterization of loess-soil complexes on the TerekKuma Plain and the Azov-Kuban' Lowland. Eurasian Soil Sci., 44, 1315-1332.

Kidder, D.L. and Worsley, T.R. (2003) Causes and consequences of extreme Permo-Triassic warming to globally equable climate and relation to the Permo-Triassic extinction and recovery. Palaeogeogr. Palaeoclimatol. Palaeoecol., 203, 207-237.

Knoll, A.H., Bamback, R.K., Canfield, D.E. and Grotzinger, J.G. (1996) Comparative earth history and the Late Permian mass extinction. Science, 273, 452-457.

Kraus, M.J. and Aslan, A. (1993) Eocene hydromorphic paleosols: significance for interpreting ancient floodplain processes. J. Sed. Petrol., 63, 453-463.

Krause, J.M., Bellosi, E.S. and Raigemborn, M.S. (2010) Lateritized tephric palaeosols from Central Patagonia: a southern high-latitude archive of Palaeogene global greenhouse conditions. Sedimentology, 57, 1721-1749.

Krull, E.S. and Retallack, G.J. (2000) $\delta^{13} \mathrm{C}_{\text {org }}$ depth profiles from palaeosols across the Permian-Triassic boundary: evidence for methane release. Geol. Soc. Am. Bull., 112, 1459-1472.

Lai, X., Wang, W., Wignall, P.B., Bond, D.P.G., Jiang, H., Ali, J.R., John, E.H. and Sun, Y. (2008) Palaeoenvironmental change during the end-Guadalupian (Permian) mass extinction in Sichuan, China. Palaeogeogr. Palaeoclimatol. Palaeoecol., 269, 78-93.

Lucas, S.G. (2009) Timing and magnitude of tetrapod extinctions across the permo-Triassic boundary. J. Asian Earth Sci., 36, 491-502.

Ludvigson, G.A., Gonzalez, L.A., Metzger, R.A., Witzke, B.J., Brenner, R.L., Murillo, A.P. and White, T.S. (1998) Meteoric sphaerosiderite lines and the use for paleohydrology and paleoclimatology. Geology, 25, 1039-1042.

McGhee, G.R., Jr, Clapham, M.E., Sheehan, P.M., Bottjer, D.J. and Droser, M.L. (2013) A new ecological-severity ranking of major Phanerozoic biodiversity crises. Palaeogeogr. Palaeoclimatol. Palaeoecol., 370, 260-270.

Michaelson, P. (2002) Mass-extinction of peat-forming plants and the effect on fluvial styles across the Permian-Triassic boundary, northern Bowen Basin, Australia. Palaeogeogr. Palaeoclimatol. Palaeoecol., 179, 173-188. 
Mitchell, R.L. and Sheldon, N.D. (2009) Weathering and paleosol formation in the $1.1 \mathrm{Ga}$ Keweenawan Rift. Precambrian Res., 168, 271-283.

Mitchell, R.L. and Sheldon, N.D. (2010) The $1100 \mathrm{Ma}$ Sturgeon Falls Paleosol revisited: implications for Mesoproterozoic weathering environments and atmospheric $\mathrm{CO}_{2}$ levels. Precambrian Res., 183, 738-748.

Morante, R. (1996) Permian and Early Triassic isotopic records of carbon and strontium in Australia and a scenario of events about the Permian-Triassic boundary. Hist. Biol., 11, 289-310.

Mundil, R., Ludwig, K.R., Metcalfe, I. and Renne, P.R. (2004) Age and timing of Permian mass extinctions: U/Pb dating of closed-system zircons. Science, 305, 1760-1763.

Nakamura, N. (1974) Determination of REE, Ba, Fe, Mg, Na, and $\mathrm{K}$ in carbonaceous and ordinary chondrites. Geochim. Cosmochim. Acta, 38, 757-775.

Nesbitt, H.W. and Young, G.M. (1982) Early Proterozoic climates and plate motions inferred from major element chemistry of lutites. Nature, 299, 715-717.

Newell, A.J., Tverdokhlebov, V.P. and Benton, M.J. (1999) Interplay of tectonics and climate on a transverse fluvial system, Upper Permian, Southern Uralian Foreland Basin, Russia. Sed. Geol., 127, 11-29.

Ogden, D.E. and Sleep, N.H. (2012) Explosive eruption of coal and basalt and the end-Permian mass-extinction. Proc. Natl Acad. Sci. US, 109, 59-62.

Ohta, T., Li, G., Hirano, H., Sakai, T., Kozai, T., Yoshikawa, T. and Kaneko, A. (2011) Early Cretaceous terrestrial weathering in Northern China: relationship between paleoclimate change and the phased evolution of the Jehol Biota. J. Geol., 119, 81-96.

Pett-Ridge, J.C., Monastra, V.M., Derry, L.A. and Chadwick, O.A. (2007) Importance of atmospheric inputs and Fe-oxides in controlling soil uranium budgets and behavior along a Hawaiian chronosequence. Chem. Geol., 244, 691-707.

Reichow, M.K., Pringle, M.S., Al'Mukhamedov, A.I., Allen, M.B., Andreichev, V.L., Buslov, M.M., Davies, C.E., Fedoseev, G.S., Fitton, J.G., Inger, S., Medvedev, A.Y., Mitchell, C., Puchkov, V.N., Safonova, I.Y., Scott, R.A. and Saunders, A.D. (2009) The timing and extent of the eruption of the Siberian Traps large igneous province: implications for the end-Permian environmental crisis. Earth Planet. Sci. Lett., 277, 9-20.

Retallack, G.J. (1995) Permian-Triassic extinction on land. Science, 267, 77-80.

Retallack, G.J. (2005) Early Triassic claystone breccias and soil erosion crisis. J. Sed. Res., 75, 663-679.

Retallack, G.J. (2008) Cambrian paleosols and landscapes of South Australia. Aust. J. Earth Sci., 55, 1083-1106.

Retallack, G.J. and Jahren, A.H. (2008) Methane release from igneous intrusion of coal during the late Permian extinction events. J. Geol., 116, 1-20.

Retallack, G.J. and Krull, E. (2006) Carbon isotopic evidence for terminal-Permian methan outbursts and their role in the extinctions of animals, plants, coral reefs, and peat swamps. In: Wetlands Through Time (Eds S.F. Greg and W.A. DiMichele), Geol. Soc. Am. Spec. Pap., 399, 249-268.

Retallack, G.J., Veevers, J.J. and Morante, R. (1996) Global coal gap between the Permian-Triassic extinction and Middle Triassic recovery of peat-forming plants. Geol. Soc. Am. Bull., 108, 195-207.

Retallack, G.J., Jahren, H., Sheldon, N.D., Chakrabarti, R., Metzger, C.A. and Smith, R.M.H. (2005) The Permian-Triassic boundary in Antarctica. Antarct. Sci., 17, 241-258.
Retallack, G.J., Metzger, C.A., Jahren, A.H., Greaver, T., Smith, R.M.H. and Sheldon, N.D. (2006) Middle-Late Permian mass extinction on land. Geol. Soc. Am. Bull., 118, 1398-1411.

Retallack, G.J., Sheldon, N.D., Carr, P.F., Fanning, M., Thompson, C.A., Williams, M.L., Jones, B.G. and Hutton, A. (2011) Multiple Early Triassic greenhouse crises impeded recovery from Late Permian mass extinction. Palaeogeogr. Palaeoclimatol. Palaeoecol., 308, 233-251. doi:10.1016/j.palaeo.2010.09.022.

Sephton, M.A., Looy, C.V., Brinkhuis, H., Wignall, P.B., de Leeuw, J.W. and Visscher, H. (2005) Catastrophic soil erosion during the end-Permian biotic crisis. Geology, 33, 941-944.

Sheldon, N.D. (2005) Do red beds indicate paleoclimatic conditions?: a Permian case study. Palaeogeogr. Palaeoclimatol. Palaeoecol., 228, 305-319.

Sheldon, N.D. (2006a) Abrupt chemical weathering increase across the Permian-Triassic boundary. Palaeogeogr. Palaeoclimatol. Palaeoecol., 231, 315-321.

Sheldon, N.D. (2006b) Quaternary glacial-interglacial climate cycles in Hawaii. J. Geol., 114, 367-376.

Sheldon, N.D. and Retallack, G.J. (2002) Low oxygen levels in earliest Triassic soils. Geology, 30, 919-922.

Sheldon, N.D. and Tabor, N.J. (2009) Quantitative paleoenvironmental and paleoclimatic reconstruction using paleosols. Earth Sci. Rev., 95, 1-52.

Sheldon, N.D., Retallack, G.J. and Tanaka, S. (2002) Geochemical climofunctions from North American soils and applications to paleosols across the Eocene-Oligocene boundary in Oregon. J. Geol., 110, 687-696.

Sheldon, N.D., Costa, E., Cabrera, L. and Garcés, M. (2012) Continental climatic and weathering response to the Eocene-Oligocene transition. J. Geol., 120, 227-236.

Shen, S.-Z., Crowley, J.L., Wang, Y., Bowring, S.A., Erwin, D.H., Sadler, P.M., Cao, C.-Q., Rothman, D.H., Henderson, C.M., Ramezani, J., Zhang, H., Shen, Y., Wang, X.-D., Wang, W., Mu, L., Li, W.-Z., Tang, Y.-G., Liu, X.-L., Liu, L.-J., Zeng, Y., Jiang, Y.-F. and Jin, Y.-G. (2011) Calibrating the end-Permian mass extinction. Sciencexpress, 334, 1367-1372.

Stanley, S.M. and Yang, X. (1994) A double mass extinction at the end of the Paleozoic era. Science, 266, 1340-1344.

Stevens, L.G., Hilton, J., Bond, D.P.G., Glasspool, I.J. and Jardine, P.E. (2011) Radiation and extinction patterns in Permian floras from North China as indicators for environmental and climate change. J. Geol. Soc. London, 168, 607-619.

Tabor, N.J., Smith, R.M.H., Steyer, J.S., Sidor, C.A. and Poulsen, C.J. (2011) The Permian Moradi Formation of northern Niger: paleosol morphology, petrography and mineralogy. Palaeogeogr. Palaeoclimatol. Palaeoecol., 299, 200-213.

Takeuchi, A., Larson, P.B. and Suzuki, K. (2007) Influence of paleorelief on the Mid-Miocene climatic variation in southeastern Washington, northeastern Oregon, and western Idaho, USA. Palaeogeogr. Palaeoclimatol. Palaeoecol., 254, 462-476.

Thomas, S.G., Tabor, N.J., Yang, W., Myers, T.S., Yang, Y. and Wang, D. (2011) Palaeosol stratigraphy across the Permian-Triassic boundary, Bogda Mountains, NW China: implications for palaeoenvironmental transition through Earth's largest mass extinction. Palaeogeogr. Palaeoclimatol. Palaeoecol., 308, 41-64. 
Tyler, G. (2004) Rare earth elements in soil and plant systems - a review. Plant Soil, 267, 191-206.

Wang, W., Cao, C.-Q. and Wang, Y. (2004) The carbon isotope excursion on GSSP candidate section of Lopingian-Guadalupian boundary. Earth Planet. Sci. Lett., 220, 57-67.

Ward, P.D., Montgomery, D.R. and Smith, R. (2000) Altered river morphology in South Africa related to the PermianTriassic extinction. Science, 289, 740-743.

Ward, P.D., Botha, J., Buick, R., de Kock, M.O., Erwin, D.H., Garrison, G., Kirschvink, J. and Smith, R. (2005) Abrupt and gradual extinction among Late Permian vertebrates in the Karoo Basin, South Africa. Science, 307, 709-714.

Weidlich, O. (2002) Permian reefs re-examined: extrinsic control mechanisms of gradual and abrupt changes during 40 my of reef evolution. Geobios Mém. Spéc., 24, 287-294.

van der Weijden, C.H. and van der Weijden, R.D. (1995) Mobility of major, minor and some redox-sensitive trace elements and rare-earth elements during weathering of four granitoids in central Portugal. Chem. Geol., 125, 149167.

Wignall, P.B., Sun, Y.-D., Bond, D.P.G., Izon, G., Newton, R.J., Vedrine, S., Widdowson, M., Ali, J.R., Lai, X.-L., Jiang, H.-S., Cope, H. and Bottrell, S.H. (2009) Volcanism, mass extinction, and carbon isotope fluctuations in the Middle Permian of China. Science, 324, 1179-1182.

Wignall, P.B., Bond, D.P.G., Kuwahara, K., Kakuwa, Y., Newton, R.G. and Poulton, S.W. (2010) An 80 million year oceanic redox history from Permian to Jurassic pelagic sediments of the Mino-Tamba terrane, SW Japan, and the original of four mass extinctions. Global Planet. Change, 71, 109-123.

Wignall, P.B., Bond, D.P.G., Haas, J., Wang, W., Jiang, H., Lai, X., Altiner, D., Védrine, S., Hips, K., Zajzon, N., Sun, Y. and Newton, R.J. (2012) Capitanian (Middle Permian) mass extinction and recovery in western Tethys: a fossil, facies, and $\delta^{13} \mathrm{C}$ study from Hungary and Hydra Island (Greece). Palaios, 27, 78-89.

Wimpenny, J., Gannoun, A., Burton, K.W., Widdowson, M., James, R.H. and Gíslason, S.R. (2007) Rhenium and osmium isotope and elemental behavior accompanying laterite formation in the Deccan region of India. Earth Planet. Sci. Lett., 261, 239-258.

de Wit, M.J., Ghosh, J.G., de Villiers, S., Rakotosolofo, N., Alexander, J., Tripathi, A. and Looy, C. (2002) Multiple organic carbon isotope reversals across the Permo-Triassic boundary of terrestrial Gondwanan sequences: clues to extinction patterns and delayed ecosystem recovery. J. Geol., 110, 227-240.
Yang, W., Feng, Q., Liu, Y., Tabor, N., Miggins, D., Crowley, J.L., Lin, J. and Thomas, S. (2010) Depositional environments and cyclo- and chronostratigraphy of uppermost Carboniferous-Lower Triassic fluvial-lacustrine deposits, southern Bogda Mountains, NW China - a terrestrial paleoclimate record of mid-latitude NE Pangea. Global Planet. Change, 73, 15-113.

Zhang, G.-L., Pan, J.-H., Huang, C.-M. and Gong, Z.-T. (2007) Geochemical features of a soil chronosequence developed on basalt in Hainan Island, China. Rev. Mex. de Ciecias Geol., 24, 261-269.

Zhou, M.-F., Malpas, J., Song, X.-Y., Robinson, P.T., Sun, M., Kennedy, A.K., Lesher, C.M. and Keays, R.R. (2002) A temporal link between the Emeishan large igneous province (SW China) and the end-Guadalupian mass extinction. Earth Planet. Sci. Lett., 196, 113-122.

Manuscript received 10 July 2013; revision accepted 17 February 2014

\section{Supporting Information}

Additional Supporting Information may be found in the online version of this article:

Figure S1. Shifts in redox across the Changhsingian-Griesbachian boundary. In contrast to the Capitanian extinction event (Fig. 9), the Changhsingian extinction demonstrates a strong redox shift towards more chemically reducing conditions. This can be seen in both the gleization $\left(\mathrm{Fe}^{2+} / \mathrm{Fe}^{3+}\right)$ ratio and $\mathrm{Eu}$ content. Data used to construct this plot are from Sheldon (2006).

Figure S2. Ce content in palaeosols across the Changhsingian-Griesbachian. In contrast to the Capitanian extinction event (Fig. 9), the Changhsingian extinction demonstrates a strong redox shift towards more chemically reducing conditions as indicated by increasing Ce content in Griesbachian palaeosols relative to Changhsingian ones. Data used to construct this plot are from Sheldon (2006).

Table S1. Major element data.

Table S2. Trace element data - Part I - complete Capitanian Extinction Section.

Table S3. Rare Earth Element and Trace Element Data - Part I - complete Capitanian Extinction Section. 